\title{
Isolation of Iranian Bacillus thuringiensis strains and characterization of lepidopteran-active cry genes
}

Maryam Rashki ${ }^{1 *}$ D, Mahmood Maleki ${ }^{2}$, Masoud Torkzadeh-Mahani ${ }^{2}$, Shahryar Shakeri ${ }^{2}$ and Pariya Soltani Nezhad ${ }^{3}$

\begin{abstract}
Background: Insecticidal crystal proteins (encoded by cry genes) produced by Bacillus thuringiensis (Bt) are fatal for insects of different orders such as Lepidoptera. The genes that encoded these crystal proteins can be detected on plasmids and chromosomal DNA and show different types in various strains. Therefore, the objective of this study was to determine molecular characteristics of Iranian Bt strains as well as their toxicity against Ephestia kuehniella (Zeller) (Lepidoptera: Pyralidae).
\end{abstract}

Results: The collection sites included fields, gardens, and desert and semi-desert areas in 8 provinces of Iran. For crystal formation, each isolate was cultured in T3 medium. The results showed that the Bt isolates produced different types of crystals including spherical (73.33\%), bipyramidal (53.33\%), irregular (40\%), cubical (33.33\%), and elliptical (13.33\%). Plasmid DNA extraction was performed and showed that most of the strains exhibited similar pattern in the number and the size of the plasmid bands to those of $B t$ kurstaki (Btk). Some specific primers were used for PCR amplification to distinguish different crystal genes including $c r y 1(A, C$, and $D$ ) and $c r y 2 A$ ( $a$ and $b$ ). The primers related to $c r y 1 D$ and cry2Aa1 genes produced no amplicons. The results revealed that the most abundant gene was cry 1 -type. All strains analyzed for the cry2Ab2 gene presented unexpected bands. Electrophoretic profile of the protein crystals showed bands with different diversity in number, and size ranged from about 16 to $140 \mathrm{KDa}$. The bioassay result of some more toxic strains exhibited that the pathogenicity of 1019 was higher than the rest, even the reference strain, Btk. However, the toxicity of other strains was the same as Btk. According to the phylogenetic tree, 1019 was located in the same group with Bt subspecies coreanensis, Bt subspecies indiana and Bt subspecies tolworthi.

Conclusions: The investigated Iranian strains had the lepidopteran-active cry genes. The strains with the same toxicity to E. kuehniella had various cry genes, plasmid, and crystal protein profiles and vice versa. Therefore, characterization of cry genes of native strains could lead to access potent isolates as biocontrol agents against native insect pests.

Keywords: Bacteria, Bioassay, Cry gene, Crystal protein, Iranian isolates, Polymerase chain reaction, Plasmid DNA

\footnotetext{
*Correspondence: ma_rashkigh@yahoo.com

'Department of Biodiversity, Institute of Science and High Technology and Environmental Sciences, Graduate University of Advanced Technology,

Kerman, Iran

Full list of author information is available at the end of the article
}

\section{Springer Open}

(c) The Author(s). 2021 Open Access This article is licensed under a Creative Commons Attribution 4.0 International License, which permits use, sharing, adaptation, distribution and reproduction in any medium or format, as long as you give appropriate credit to the original author(s) and the source, provide a link to the Creative Commons licence, and indicate if changes were made. The images or other third party material in this article are included in the article's Creative Commons licence, unless indicated otherwise in a credit line to the material. If material is not included in the article's Creative Commons licence and your intended use is not permitted by statutory regulation or exceeds the permitted use, you will need to obtain permission directly from the copyright holder. To view a copy of this licence, visit http://creativecommons.org/licenses/by/4.0/. 


\section{Background}

Insecticidal crystal proteins (encoded by cry genes) produced by a gram-positive bacterium, Bacillus thuringiensis (Bt) (Nazarian et al., 2009) are fatal for insects of different orders such as Lepidoptera, Coleoptera, and Diptera (Aronson and Shai, 2001). In addition, when the toxic genes are expressed in transgenic crops, they can control the pest populations such as Lepidoptera (Boukedi et al., 2016). The classification of crystal toxins of $B t$ has shown that there are 73 families and 6 groups of endotoxin proteins (Palma et al., 2014).

The genes that encoded these crystal proteins can be detected on plasmids and chromosomal DNA (Höfte and Whiteley 1989) and show different types in various strains. For example, $c r y 1 A a, c r y 1 A c, c r y 2 A a$, and $c r y 2 A b$ were discovered in $B t$ subspecies kurstaki (Btk) (Baum and Malvar 1995). However, cry7A and cry $1 B$ were found in Bt subspecies galleriae (Btg) (Nazarian et al., 2009).

Some cases of resistance of insect pests to crystal toxins have been observed even in the commercial isolate of Bt (Tamez-Guerra et al., 2006). Therefore, many studies have been carried out to isolate and characterize new and native isolates. For instance, Yilmaz et al. (2012) introduced 6 cry genes including cry $1 C$, crylAa/ $A d, \operatorname{cry} 1 B, \operatorname{cry} 5, \operatorname{cry} 9 A$, and $\operatorname{cry} 9 \mathrm{C}$ belonging to a novel strain (SY49.1) isolated from Turkey. A new isolate of $B t$, harboring cry30, cry 40 , and cry54 genes, was described by Boukedi et al. (2016) from Tunisia. The Iranian $B t$ strains containing lepidopteran-specific cry genes like cry1, cry2, and cry9 were presented (Seifinejad et al., 2008).

$B t$ is able to insert through the peritrophic membrane and midgut epithelium and overcome the insect immune system (Raymond, 2017). In fact, the protoxins of $B t$ are activated in the insect gut when they encounter the high $\mathrm{pH}$, then bind to receptors located on midgut brush border membrane vesicles, and finally cause cell destruction and host death (Bravo et al., 2017).

Most of the bioassay investigation revealed that the natural strains could be efficient with high pathogenicity against insect pests. The pathogenesis of IS5053 strain was similar to the Btk against Trichoplusia ni (Hübner) (Lepidoptera: Noctuidae) (Swiecicka et al., 2008). However, the SY49.1 strain showed high mortality for Ephestia kuehniella (Zeller) (Lepidoptera: Pyralidae) and Plodia interpunctella (Hübner) (Lepidoptera: Pyralidae) (Yilmaz et al., 2012) in comparison with Btk. Efficacy of BLB250 strain against 2 lepidopteran pests, Spodoptera littoralis (Boisduval) (Lepidoptera: Noctuidae) and E. kuehniella was estimated, and the novel strain showed higher toxicity than the $2 \mathrm{Bt}$ reference strains (BenFarhat-Touzri et al., 2016).

Despite of many preceding reports of $B t$ crystal protein genes, isolation and characterization of more indigenous isolates are essential. The objective of this study was to determine molecular characteristics of $B t$ strains as well as their toxicity against E. kuehniella. These isolates were obtained from soil samples in Iran.

\section{Methods \\ Soil collection}

Soil was collected in 50-ml sterile Falcon tubes from the depth of $5-10 \mathrm{~cm}$. The samples were labeled and transported to the laboratory and were incubated at $4{ }^{\circ} \mathrm{C}$. The collection sites included fields, gardens, and desert and semi-desert areas in 8 provinces of Iran.

\section{Bacterial isolation and identification}

$B t$ isolates were obtained from the soil samples according to the method of Travers et al. (1987). Sodium acetate $(0.25 \mathrm{M})$ was added to Luria Bertani (LB) broth (20 $\mathrm{ml}$ ), and then, $1 \mathrm{~g}$ of soil sample was poured into the buffer. The mixture was shaked at $200 \mathrm{rpm}$ for $4 \mathrm{~h}$ at 30 ${ }^{\circ} \mathrm{C}$. Then, each sample $(1 \mathrm{ml})$ was heated at $80{ }^{\circ} \mathrm{C}$ for 10 min. A 50-ml suspension was transferred and cultured onto a nutrient agar (NA) (containing $0.5 \%$ peptone, $0.3 \%$ beef and yeast extracts, $1.5 \%$ agar, and $0.5 \%$ sodium chloride) Petri dish (8-cm diameter). The cultures were incubated at $35{ }^{\circ} \mathrm{C}$, and $\mathrm{Bt}$-like colonies were sub-cultured. The bacteria were observed under a light microscope after Gram staining. Three reference strains were used including $B t$ subsp. kurstaki (Btk), Bt subsp. thuringiensis (Btt), and $B t$ subsp. galleriae (Btg) (Persian Type Culture Collection in Iranian Research Organization for Science and Technology, Tehran, Iran). All $B t$ isolates were stored at $-80{ }^{\circ} \mathrm{C}$ in $15 \%$ glycerol stock.

\section{Crystal morphology}

For parasporal crystal formation, each isolate was cultured in T3 medium ( $3 \mathrm{~g}$ triptone, $2 \mathrm{~g}$ triptose, $1.5 \mathrm{~g}$ yeast extract, $0.005 \mathrm{~g} \mathrm{MnCl} 2,6 \mathrm{~g} \mathrm{NaH} 2 \mathrm{PO} 4$, and $7.1 \mathrm{~g}$ Na2HPO4) (Travers et al., 1987). For sporulation, the culture was incubated at $30{ }^{\circ} \mathrm{C}, 200 \mathrm{rpm}$ for 7 days. Pellet of the culture was obtained $(15,000 \times g$ for $10 \mathrm{~min})$ and was washed twice and centrifuged again in sterile distilled water. The pellet containing spore-crystal mixture was freeze dried and used for observation under phase contrast microscope by coomassie blue staining to examine the presence of crystals. The spore-crystal mixture of the high pathogenic isolate was evaluated by electron microscopy.

\section{Isolation of plasmid DNA}

Plasmid DNA extraction was performed by using the method of Sambrook et al. (1989). The GeneAll ${ }^{\circ}$ Exprep $^{\mathrm{TM}}$ Plasmid DNA kit (South Korea, GeneAll Biotechnology) was used according to the manufacturer's instructions. Each isolate of $B t$ was grown in $10 \mathrm{ml} \mathrm{LB}$ for $16 \mathrm{~h}$ at $37^{\circ} \mathrm{C}$ and shaked at $160 \mathrm{rpm}$. The bacterial 
culture was centrifuged at $10,000 \times \mathrm{g}$ for $5 \mathrm{~min}$, and the supernatant was removed. The pellet was resuspended in $250 \mu \mathrm{l}$ of buffer 1 in the presence of RNase to release the plasmid DNA into supernatant.

To completely disrupt base pairing, $250 \mu \mathrm{l}$ of buffer 2 was added and mixed by inverting. After adding $350 \mu \mathrm{l}$ of buffer 3, the solution was centrifuged for $10 \mathrm{~min}$. The cleared lysate was transferred to a column and centrifuged again for $30 \mathrm{~s}$. Buffers $4(500 \mu \mathrm{l})$ and $5(700 \mu \mathrm{l})$ were separately applied into the column and centrifuged for $30 \mathrm{~s}$. Finally, $50 \mu \mathrm{l}$ of $10 \mathrm{mM}$ Tris (pH 8.5) was applied and incubated for $1 \mathrm{~min}$. Following elimination, the residual wash buffer, the optimal elution of DNA, was obtained and subjected to electrophoresis in $0.5 \%$ agarose gel.

\section{Polymerase chain reaction (PCR)}

Plasmid DNA of each isolate and the reference strain was used for PCR as DNA template. PCR analysis was carried out according to Juarez-Perez et al. (1997), using the 6 primers to distinguish the pertaining cry genes (Table 1). Each PCR mixture $(25 \mu \mathrm{l})$ was composed of Super PCR MasterMix $(12.5 \mu \mathrm{l})$, primer $(2 \mu \mathrm{l}$ of both forward and reverse), $2 \mu \mathrm{l}$ DNA template $(\mu \mathrm{l})$ and $8.5 \mu \mathrm{l}$ of distilled water.

The PCR program for the primers was as follows: initial denaturation at $95{ }^{\circ} \mathrm{C}$ for $3 \mathrm{~min}$, followed by 35 cycles for denaturation at $94{ }^{\circ} \mathrm{C}$ for $1 \mathrm{~min}, 35$ cycles for annealing (different for each primer pairs) for $1 \mathrm{~min}$ and extension step at $72{ }^{\circ} \mathrm{C}$ for $1 \mathrm{~min}$, and last extension at $72{ }^{\circ} \mathrm{C}$ for $5 \mathrm{~min}$. At the annealing part, the first cycle with a decrease of $5{ }^{\circ} \mathrm{C}$ was only conducted to detect cry $1 A a$, cry $1 C$, and $c r y 2 A b 2$.

\section{S ITS rDNA gene analysis}

Phylogenetic analysis was conducted, using the highest pathogenic isolate, 1019 (NCBI (National Center for Biotechnology Information) Accession No. MW485925), and the universal primer (Table 1). Other type strains with more than $99 \%$ sequence identity and B. subtilis subspecies natto as an out-group were used for the analysis. By the BLAST tool at the NCBI website (http://www. ncbi.nlm.com), the nucleotide sequence was analyzed to identify the bacterium based on sequence similarity.

The selected sequences from NCBI and 1019, were aligned using MAFFTv.7 (Katoh and Standley, 2013) with "Auto" settings; and then inspected manually by Mesquite v. 3.10 (Maddison and Maddison, 2015). The Linux version of IQ-tree (Nguyen et al. 2015) was used to build a Maximum likelihood tree to determine the phylogenetic relationship among aligned sequences. The created tree was visualized, using Figtree v.1.4.3 (http:// tree.bio.ed.ac.uk/software/figtree/).

\section{Protein electrophoresis}

The sodium dodecyl sulfate-polyacrylamide gel electrophoresis (SDS-PAGE) was executed to determine the protein profiles of crystal components as described by Laemmli (1970). Hence, each spore-crystal mixture was added in a sample buffer and heated at $75{ }^{\circ} \mathrm{C}$ for $15-20$ min. The buffer contents were $4 \mathrm{ml} \mathrm{10 \%} \mathrm{SDS,} 2 \mathrm{ml}$ glycerol, $1.2 \mathrm{ml}$ of $1 \mathrm{M}$ Tris (pH 6.8), $0.01 \%$ bromophenol blue, $10 \mathrm{ml} \beta$-mercaptoethanol, and $2.8 \mathrm{ml} \mathrm{dH} 2 \mathrm{O}$.

The protein samples of $B t$ isolates were loaded onto the acrylamide gel containing a $12 \%$ separating gel with a $5 \%$ stacking gel. Comassie brilliant blue R250 (0.1\%) was used to stain the gel, and then the gel was destained.

Table 1 Characteristics of primers for screening of cry-type and 16S-ITS rDNA region genes

\begin{tabular}{|c|c|c|c|}
\hline Primer name & Melting temperature $\left({ }^{\circ} \mathrm{C}\right)$ & $\begin{array}{l}\text { Sequence } \\
\left(5^{\prime} \rightarrow 3^{\prime}\right)\end{array}$ & Reference \\
\hline $16 \mathrm{~S}$ ITS rDNA(F) & 60 & AGAGTTTGATCCTGGCTCAG & Yılmaz et al., (2012) \\
\hline 16S ITS rDNA(R) & 53 & CAAGGCATCCACCGT & \\
\hline Spcry1Aa (F) & 54 & TTCCCTTATTTGGGAATGC & Seifinejad et al. (2008) \\
\hline UNcry1 (R) & 51 & MDATYTCTAKRTCTTGACTA & \\
\hline Lep2 (F) & 58 & CCGAGAAAGTCAAACATGCG & Boukedi et al. (2016) \\
\hline Lep2 (R) & 58 & TACATGCCCTTTCACGTTCC & \\
\hline St2C (F) & 56 & GGGACATTCCTTCGTTTCG & BenFarhat-Touzri et al. (2016) \\
\hline St2Cinv(R) & 54 & GGTGTTCCAGATCTTTGAAC & \\
\hline St1D (F) & 49 & ATGGAAATAAATAATCAAAACC & BenFarhat-Touzri et al. (2016) \\
\hline St1Dinv (R) & 51 & ACTAGATTGGATACCTGATC & \\
\hline UNery2 (F) & 55 & CGGATAAAATAATCTGGGAAATAGT & Salehi Jouzani et al. (2008) \\
\hline SPcry2Aa (R) & 57 & GAGATTAGTCGCCCCTATGAG & \\
\hline UNcry2 (F) & 55 & CGGATAAAATAATCTGGGAAATAGT & Salehi Jouzani et al. (2008) \\
\hline SPcry2Ab (R) & 65 & TGGCGTTAACAATGGGGGGAGAAAT & \\
\hline
\end{tabular}




\section{Insect culture and bioassays}

The Mediterranean flour moth, E. kuehniella, was reared on a mix of flour and yeast (10:1) diet under laboratory conditions $\left(27 \pm 1{ }^{\circ} \mathrm{C}, 60 \pm 5 \% \mathrm{RH}, 16 \mathrm{~L}\right.$ (Light): $8 \mathrm{D}$ (Dark)), and the insecticidal activity of 9 high pathogenic isolates of $B t$ was examined against 12-day-old larvae. Accordingly, the bacterial isolates were grown on nutrient agar Petri dishes $\left(8-\mathrm{cm}\right.$ diameter) at $35^{\circ} \mathrm{C}$. After 7 days, the spore-crystal mixtures were harvested by a loop tool and added to $10 \mathrm{ml}$ of sterile distilled water with Tween $80(0.02 \%)$.

Different concentrations of each $B t$ isolate and control (Tween $80(0.02 \%))$ were prepared. The reference strain, $B t k$, was used as a positive control. Experimental unit was a Petri dish (5.8 $\mathrm{cm}$ diameter) containing fifteen 12day-old larvae fed on $1 \mathrm{~g}$ of the described diet. For bioassays, the diet described above was mixed with $1 \mathrm{ml}$ of each concentration. Each treatment and the control were repeated three times at $27 \pm 1{ }^{\circ} \mathrm{C}, 60 \pm 5 \% \mathrm{RH}$ and a photoperiod of 16L: 8D. The larvae were fed for 14 days, and during the period, dead larvae were checked and recorded daily.

\section{Statistical analysis}

The bioassay analysis was conducted using POLO-PC software (2002), and consequently, the value of $\mathrm{LC}_{50}$ (median lethal concentration) for each isolate was estimated.

\section{Results}

\section{Bacterial isolation and identification}

After checking the bacterial cultures, some Bt-like colonies were selected according their appearances. The colonies were cream colored or white, almost circular, and smooth or rough. All selected bacterial samples were gram positive.

\section{Crystal morphology}

The crystal-forming $B t$ strains were identified under a phase contrast microscope. The results showed that the $B t$ isolates produced different types of crystals including spherical (73.33\%), bipyramidal (53.33\%), irregular (40\%), cubical (33.33\%), and elliptical (13.33\%). All isolates structured more than one type of crystal protein except 1036 (spherical type). The high pathogenic isolate, 1019, was examined by scanning electron microscopy. It was detected that the isolate produced the bipyramidal and spherical crystals (Fig. 1).

\section{Isolation of plasmid DNA}

Agarose gel electrophoresis showed different plasmid profiles for the native and reference isolates (Fig. 2). Nevertheless, most of the isolates exhibited similar pattern in the number and size of the plasmid bands to those of Btk. However, in the present study, the 1020 strain was similar to Btg, there was a small band in the native strain that was not appeared in the reference strain. Each of the 1032, 1033, 1036 and 1037 isolates presented variations in the plasmid profiles and the patterns were also different from the reference isolates. Moreover, all isolates showed the chromosomal DNA band, and there was only an obvious band for the 1032 isolate above the chromosomal band in terms of megaplasmid.

\section{Polymerase chain reaction (PCR)}

Specific primers were used for PCR amplification to distinguish different crystal genes including $\operatorname{cry} 1(A, C$, and

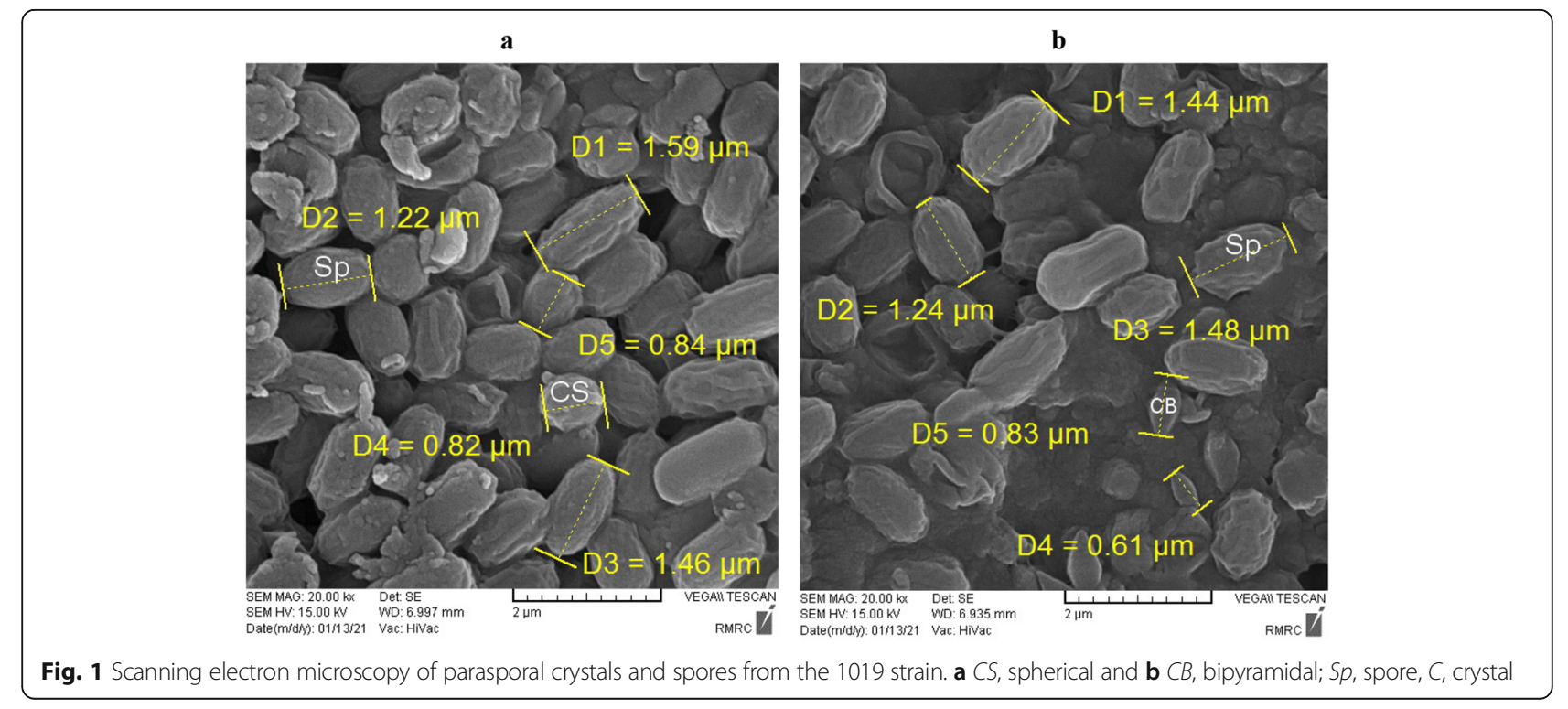




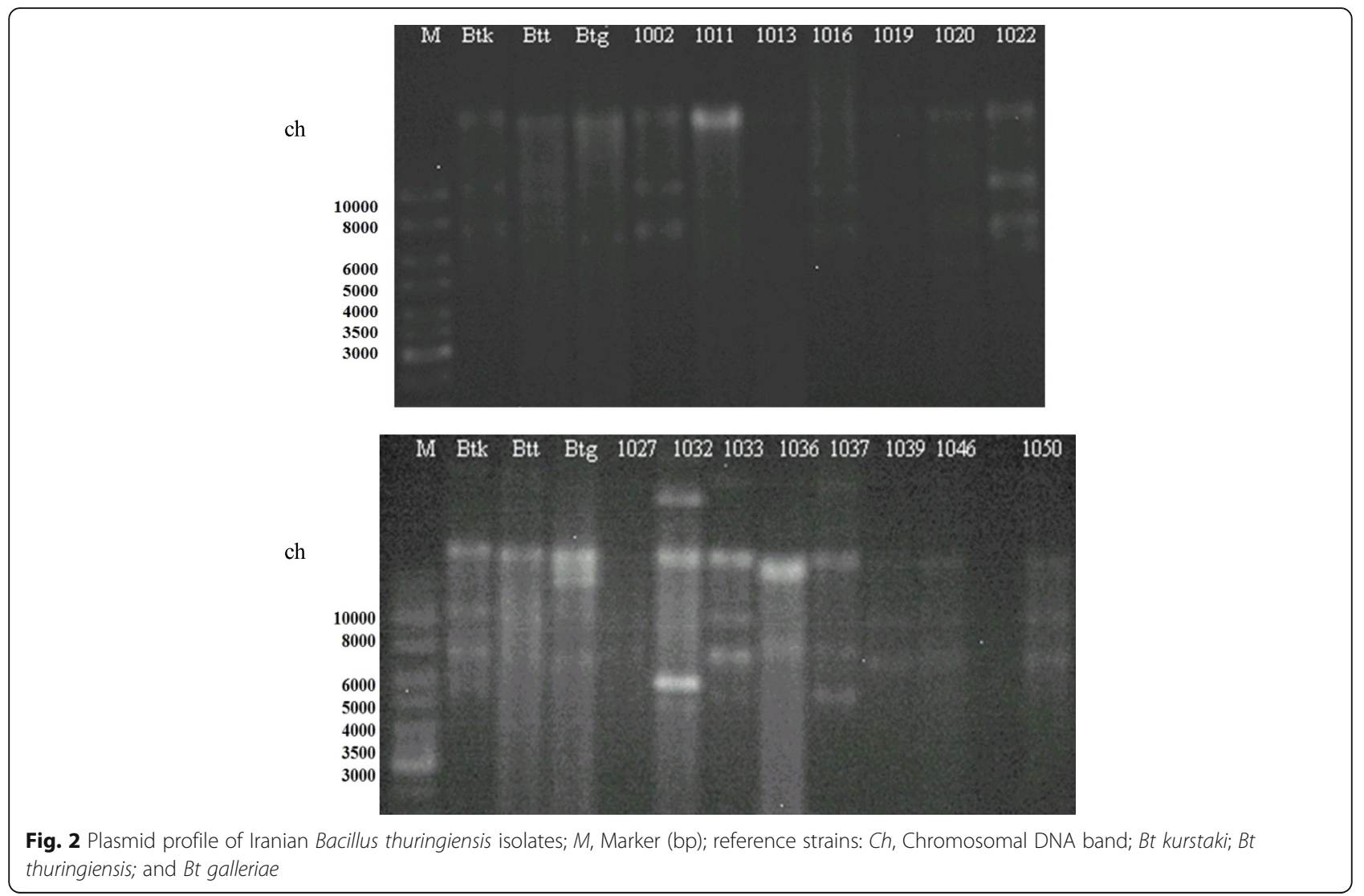

$D)$ and $\operatorname{cry} 2 A$ ( $a$ and $b$ ). The primers related to $\operatorname{cry} 1 D$ and $c r y 2 A a 1$ genes produced no amplicons. All isolates exhibited to contain the $c r y 1 A$ with primer pairs Lep2 (Fig. 3a) and produced bands of the expected size. Some isolates including 1020 (986 bp) (NCBI Accession No. MW526365), 1022 (986 bp) (NCBI Accession No. MW567501), and 1032 (986 bp) (NCBI Accession No. MW567502) were randomly selected. The sequencing results declared their homology with cry1Ac.

In the present study, PCR unexpected band with a size of approximately $600 \mathrm{bp}$, corresponding to $\mathrm{cry} 1 \mathrm{Aa}$, were achieved for the 1032 isolate (Fig. 3b). Nevertheless, the 1002 and 1033 isolates produced bands of expected sizes, and the rest of isolates did not harbor any gene. All isolates with the exception of 1002 and 1046 were positive for the presence of $c r y 1 C$ (Fig. 3c). The 1033 isolate was only sequenced (895 bp) (NCBI Accession No. MW526366) and the gene had high identity to $c r y 1 C b$. All $B t$ isolates analyzed for the $c r y 2 A b 2$ gene presented unexpected bands (Fig. 3d). However, the 1013, 1019, 1032, 1036, and 1046 isolates did not show any band.

\section{S ITS rDNA gene analysis}

The 16S ITS rDNA gene analysis of the 1019 isolate was conducted based on the gene sequence. Based on the
NCBI database, the BLAST results of the sequence showed more than $99 \%$ identity to all $B t$ strains used. According to the phylogenetic tree, 1019 was located in the same group with $B t$ subspecies coreanensis, $B t$ subspecies indiana, and $B t$ subspecies tolworthi (Fig. 4).

\section{Protein electrophoresis}

Electrophoretic profile of the Iranian isolates was characterized by SDS-PAGE analysis and compared (Fig. 5). The protein patterns of tested isolates showed bands with different diversity in number and size ranged from about 16 to $140 \mathrm{KDa}$. Likewise, the results clarified that the most of shared bands produced above $45 \mathrm{KDa}$. The 2 isolates, 1013 and 1032 individually had unique protein pattern. Among the tested isolates, 1022 and 1046 nearly produced the same protein profiles that differed from the rest. The patterns created by the other isolates were almost similar and especially shared major protein bands with molecular weights of about $16,17,28$, and $50 \mathrm{KDa}$, and a group of bands between about 45 and $140 \mathrm{KDa}$.

\section{Bioassays}

The results in Table 2 exhibited that the pathogenicity of 1019 strain was higher (with the lowest value of $\mathrm{LC}_{50}$ ) than the rest, even the reference strain, Btk. However, the toxicity of other strains was the same as Btk. The 


\section{a}

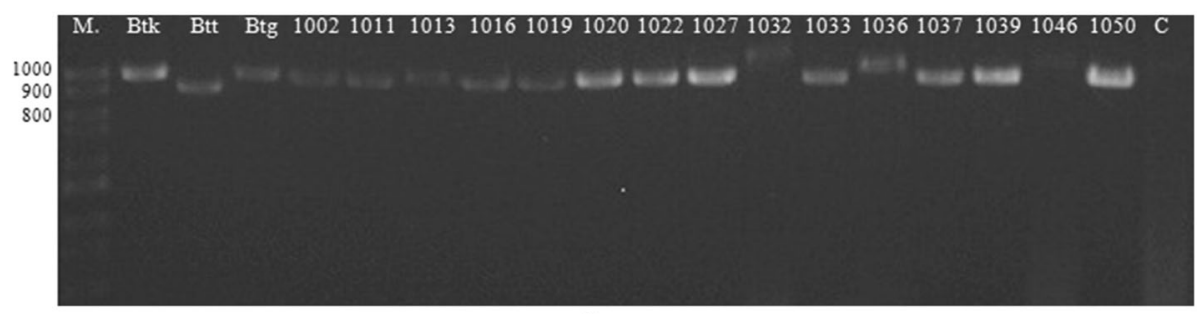

b

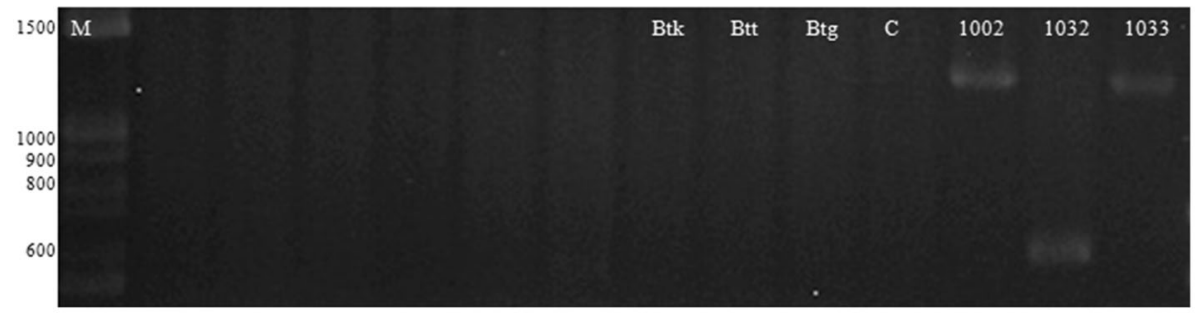

c

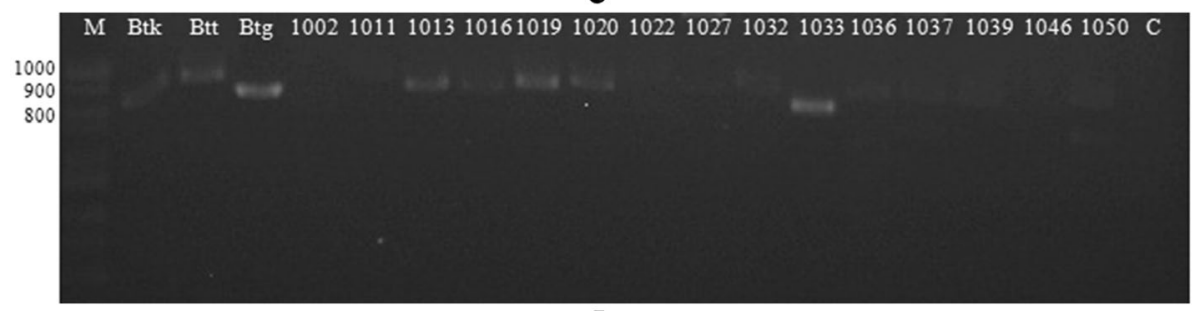

d

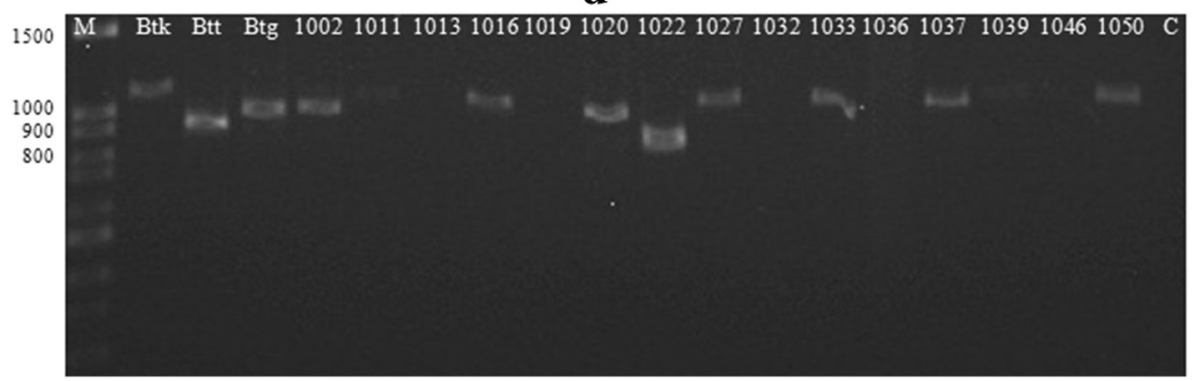

Fig. 3 Agarose gel (1\%) electrophoresis of PCR products obtained from the Iranian Bacillus thuringiensis strains. a With Lep2, b Spcry1Aa, c St2C, d UNcry2 primer pairs; reference strains: Bt kurstaki, Bt thuringiensis, and Bt galleriae; C, negative control; M, Marker (100 bp)

1032, 1037, and 1039 isolates had similar median lethal concentrations.

\section{Discussion}

The present study determined the characterization of some $B t$ strains collected from various biomes and sites of Iran. The results showed that 73.33 and $53.33 \%$ of the isolates produced spherical and bipyramidal crystals, respectively, compared to those of Seifinejad et al. (2008) who reported that most of Iranian isolates created bipyramidal ones. Similar to the obtained results, extraordinary variations of crystals (like spherical, irregular, bipyramidal) were observed among native $B t$ isolates collected from soil and other materials by El-kersh et al. (2016).
Among different characteristics of Bt strains, the plasmid profiles could help to identify strains (Saadaoui et al., 2010). Our result was in accordance with that of BenFarhat-Touzri et al. (2016), who demonstrated that BLB250 strain was identical to Bt strain aizawai and concluded that the strain might be a serotype of the reference isolate. Present study indicated also that some isolates from various regions and provinces had different plasmid profile even in comparison with the reference strains.

Likewise, Yilmaz et al. (2012) found several forms of plasmid patterns in the SY49.1 strain compared with Btk like Seifinejad et al. (2008) for Iranian isolates. Although, the 1013 and 1019 isolates were collected from different provinces, they showed the same pattern and produced one band. 


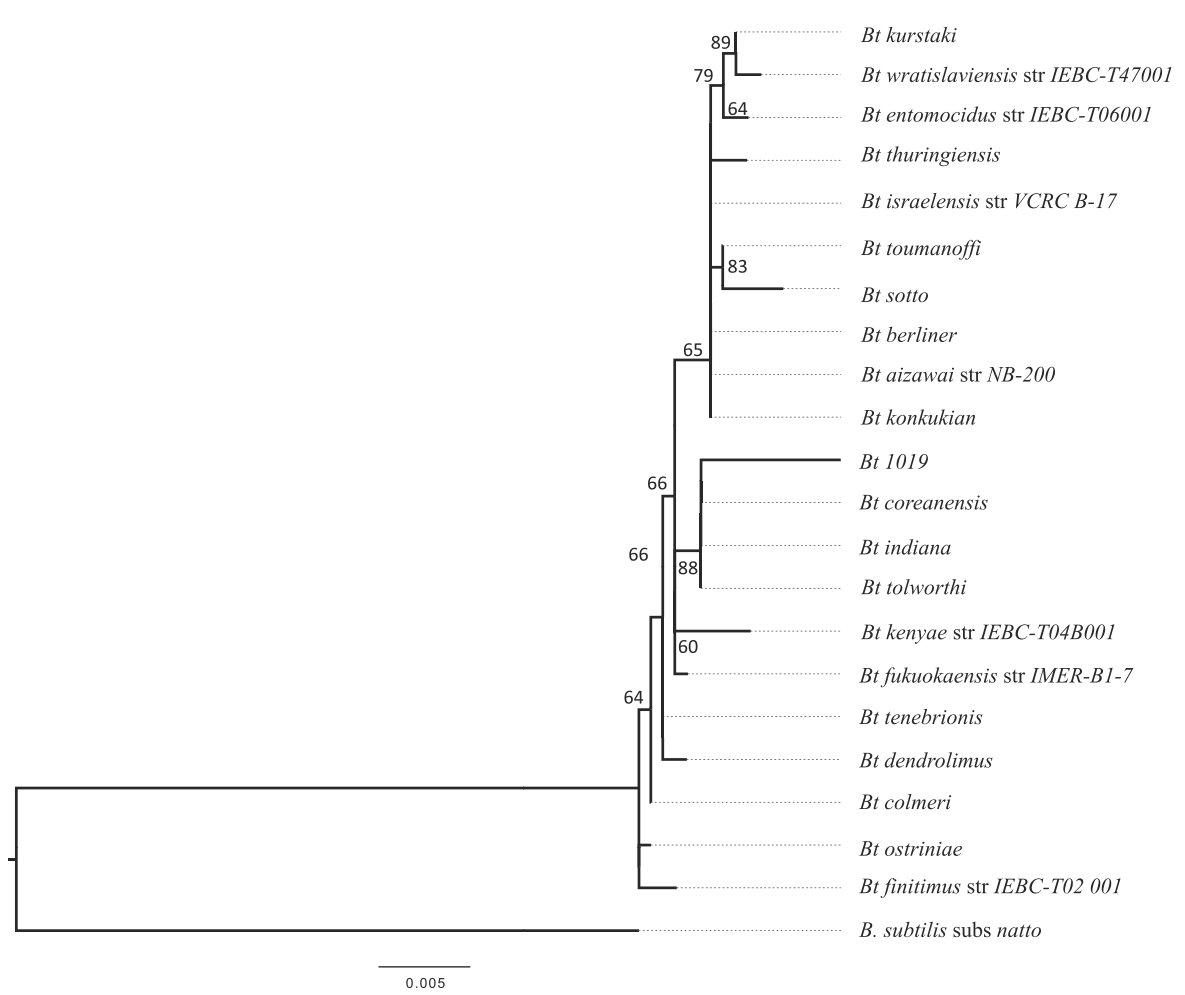

Fig. 4 Phylogenetic tree of 20 Bacillus thuringiensis isolates obtained from NCBI along with the native isolate (1019) and Bacillus subtilis subspecies natto as an out-group showing relationships between the alignment of the $1450 \mathrm{bp}$ of 165 -ITS rDNA region. The horizontal bar represents $0.05 \%$ variation in nucleotide identities

Due to genetic diversity observed in the $B t$ strains and containing more than one cry gene located on the plasmids or chromosomes, polymerase chain reaction (PCR) can be a precise procedure to discover and characterize the genes (Salama et al., 2015). In the present study, all isolates exhibited bands of the expected size for $\operatorname{cry} 1 A$, and few ones showed the expected bands for cry1Aa. Similar bands of the expected size for $\operatorname{cry} 1 \mathrm{~A}$ have been reported for new strains isolated from Tunisian soil samples with the primer pairs (BenFarhat-Touzri et al., 2016). On the contrary, Seifinejad et al. (2008) manifested that $\operatorname{cry} 1 A a$ was the most abundant gene belonging to the strains isolated from different regions of Iran. Most of the strains harbored $c r y 1 C$ that was consistent with Seifinejad et al. (2008). However, previous study

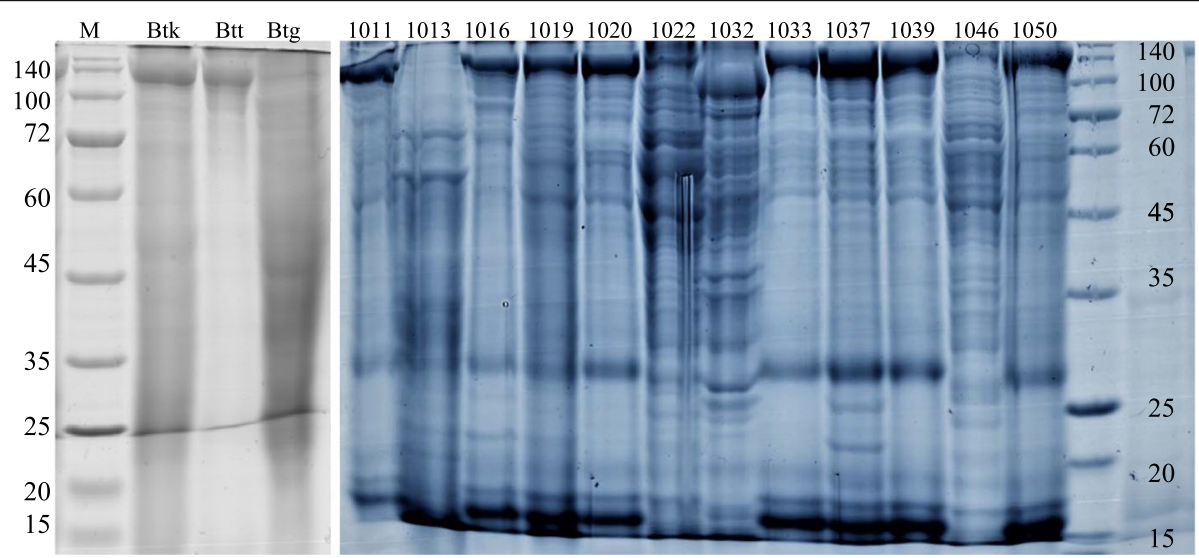

Fig. 5 SDS-PAGE of spore-crystal mixture from Iranian Bacillus thuringiensis strains; M, marker. Reference strains: Bt kurstaki, Bt thuringiensis, and Bt galleriae 
Table 2 Mean lethal concentrations ( $\left(\mathrm{CC}_{50}\right)$ of Ephestia kuehniella infected with some Iranian Bacillus thuringiensis strains

\begin{tabular}{lllll}
\hline $\begin{array}{llll}\text { Bt } \\
\text { strain }\end{array}$ & $\begin{array}{l}\mathbf{L C}_{\mathbf{5 0}} \\
\text { spore/ml }\end{array}$ & \multicolumn{2}{l}{$\mathbf{9 5 \% \text { Confidence intervals }}$} & \multirow{2}{*}{$\boldsymbol{X}^{\mathbf{2}}$} \\
\cline { 3 - 4 } & $3.09 \times 10^{6}$ & $6.17 \times 10^{5}$ & $1.30 \times 10^{7}$ & 5.35 \\
\hline 1019 & Lower & Upper & \\
1032 & $6.20 \times 10^{7}$ & $1.80 \times 10^{7}$ & $3.80 \times 10^{8}$ & 1.58 \\
1037 & $7.70 \times 10^{7}$ & $2.16 \times 10^{7}$ & $5.18 \times 10^{8}$ & 2.15 \\
1039 & $1.40 \times 10^{7}$ & $5.11 \times 10^{6}$ & $3.8 \times 10^{7}$ & 1.25 \\
Btk & $2.90 \times 10^{7}$ & $9.60 \times 10^{6}$ & $1.90 \times 10^{8}$ & 1.07 \\
\hline
\end{tabular}

showed that cry genes isolated from Iran exhibited unexpected size bands for cry $1 C$ (Nazarian et al., 2009).

Totally, the findings of the present study are similar to those presented by Bravo et al. (1998) who reported that the most abundant gene was cry1 among the Mexican strains collected from soil samples. Compatible to our results, characterization of the strains isolated from Egyptian soil samples clarified that $77.77 \%$ of them contained the cry1C genes (Salama et al., 2015). Similar to the present study, Yilmaz et al. (2012) found that cry $1 A$ along with $c r y 1 C$ from the most pathogenic $B t$ strain (SY49.1) collected from Turkey. By comparison, Salehi Jouzani et al. (2008) elucidated that the most abundant gene detected from Iranian isolates was cry2-type such as $c r y 2 A b$ (55\%) and $c r y 2 A a 1$ (37.5\%). Compatible to the obtained results, all Iranian $B t$ strains isolated from soil and larvae harbored the cry 2 gene, and some of them showed amplification products for cry1Ac, cry1Aa, and cry1C (Khorramnejad et al., 2018).

The results of the sequence analyzing of the highest pathogenic strain, 1019, showed more than $(99 \%)$ identity to all $B t$ strains used. Yilmaz et al. (2012) analyzed the 16S ITS rDNA gene of the SY49.1 strain and indicated that the similarity of the tested strain was (98\%) with $B t$ subspecies andalousiensis BGSC 4AW1 and Bt subspecies monterrey BGSC 4AJ1. Moreover, the $16 S$ $r R N A$ gene analysis of native $B t$ isolates reported by Elkersh et al. (2016) showed that the high pathogenic isolate, Bt63, had a strict relationship to $B t$ subspecies israelensis, and all isolates were homologous together. Consistent with our output, analysis of an Indian strain by the gene sequencing revealed high identity with $B$. $c e$ reus and Bt (Banik et al., 2019).

A previous investigation revealed that molecular mass of Cry1Aa, Cry1Ac, and Cry1C proteins were 133.2, 133.3, and $134.8 \mathrm{kDa}$ analyzed through the SDS-PAGE, respectively (Kalman et al., 1995). All strains studied by Alper et al. (2016), harboring the cry1 and cry 2 genes, and the reference strain, $B t k$, almost revealed similar crystal protein contents. Similar results have been achieved for the most Iranian strains studied in the present research. It was shown that all protein profiles of Iranian strains were almost similar to the reference strains, Btk and Btt, except those of 1013, 1022, 1032, and 1046 that were almost similar to the Btg protein pattern.

According to the present results, the 1013 and 1032 strains had different protein profiles. Both of them carried $\operatorname{cry} 1 A c$ and cry $1 C$; however, 1032 only showed an unexpected band for cry1Aa. Both of the 1022 and 1046 strains, with similar protein patterns, had $c r y 1 A c$; however, the 1022 strain harbored 2 extra genes including cry $1 C$ and cry2Ab2. Khorramnejad et al. (2018) clarified that the protein patterns of tested strains were similar to Btk with molecular mass between 60 and $130 \mathrm{kDa}$ comprising Cry1Aa, Cry1Ab, Cry1Ac, Cry1Ca, Cry1Da, and Cry2Aa proteins. Also, these profiles were observed for the tested crystals in the present study.

Based on previous study, more than $50 \%$ of Iranian isolates structured proteins of $130-140 \mathrm{kDa}$, and there were also strains that produced proteins with a molecular mass between 28 and $140 \mathrm{kDa}$ or even lower than 28 $\mathrm{kDa}$ (Seifinejad et al., 2008), in which the first range was active against lepidopteran pests (Herandeza et al., 2005) that was in accordance with our findings. Additionally, the most of Iranian strains which harbored cry2-type genes showed protein bands of 21-140 kDa (Salehi Jouzani et al., 2008). Boukedi et al. (2016) reported that Bt HD1 and BUPM95 carried Cry proteins of 65-70 and 130-135 kDa related to the cry 2 and cry 1 genes, respectively. All investigations mentioned above for protein profiles of parasporal inclusions were in accordance with our results and confirmed that the Iranian strains were able to produce effective crystal protein toxin against lepidopteran pests, and the toxins were associated to their PCR profiles.

It was obvious that the cry 1 and cry $2 A$ genes are active against lepidopteran insects (Park et al., 2011). Although, all tested strains especially 1019 were analyzed for the $c r y 1 A$ and $c r y 1 C$ genes and presented expected bands, they manifested different median lethal concentrations. Similarly, the high toxic Turkish strain, SY49.1, against E. kuehniella harbored the two latter genes (Yilmaz et al., 2012). Furthermore, E. kuehniella was so sensitive to the novel strain, BLB250, as it contained cry1A (BenFarhat-Touzri et al., 2016). Jalapathi et al. (2020) indicated that Cry1Ac protein toxin from $B t$ was highly pathogenic to the larvae of Tuta absoluta (Meyrick) (Gelechiidae: Lepidoptera) which was in accordance with our results. As it was obvious, our findings were consistent with those of previous outcomes, and the important role of $c r y 1$, as a determinant of pathogenicity against lepidopteran pests, was supported by the current results.

Consistent with this research, 2 Iranian strains, KON4 and YD5, harboring $\operatorname{cry} 1 A, \operatorname{cry} 1 C$, and $\operatorname{cry} 2 A$, were more 
pathogenic against Helicoverpa armigera (Hübner) larvae than Btk (Seifinejad et al., 2008). The highest mortality for E. kuehniella happened by the Tunisia isolate, BLB1, harboring cry 1 and cry 2 in comparison with Btk HD1 (Saadaoui et al., 2010). In comparison with the current bioassay result, some Turkish $B t$ strains harboring cry $2 A b$ and $c r y 2 A a 1$ led to $42 \%$ mortality in E. kuehniella (higher than Btk) (Alper et al., 2016).

The investigated Iranian strains had the lepidopteranactive $c r y$ genes; however, their toxicity potential against the Mediterranean flour moth varied. This finding was in close agreement with Ferrandis et al. (1999) that exhibited the inactivation possibility of the specific genes.

\section{Conclusions}

The present study found out that cryl was the most abundant gene. Nonetheless, the strains that presented unexpected size bands might harbor putative novel cry genes against a new spectrum of insect pests. Likewise, it was concluded that the strains with the same toxicity to the Mediterranean flour moth had various cry genes, plasmid and crystal protein profiles, and vice versa. Therefore, characterization of cry genes of native strains could lead to access potent isolates as biocontrol agents against native insect pests.

\section{Abbreviations \\ Bt: Bacillus thuringiensis; Btg: Bacillus thuringiensis subspecies galleriae; Btk: Bacillus thuringiensis subspecies kurstaki; Btt: Bacillus thuringiensis subspecies thuringiensis; C: Crystal; CB: Bipyramidal crystal; CS: Spherical crystal; D: Dark; L: Light; LB: Luria Bertani; LC $_{50}$ : Median lethal concentration; NA: Nutrient agar; NCBI: National Center for Biotechnology Information; PCR: Polymerase chain reaction; RH: Relative humidity; SDS-PAGE: Sodium dodecyl sulfate-polyacrylamide gel electrophoresis; Sp: Spore}

\section{Acknowledgements}

Not applicable

\section{Authors' contributions}

MR created the research plan, analyzed the data, and wrote the paper. MM, MT, and SS were advisors, and PSN performed the experiments. The authors read and approved the final manuscript.

\section{Funding}

The research funding was provided for this project (No. 96003008) by Iran National Science Foundation (INSF) and Graduate University of Advanced Technology, Kerman, Iran (No. 7/S/96/3665). Both of the funding bodies financially supported all aspects of the study including materials, collection, sequencing, and analysis.

\section{Availability of data and materials}

The datasets used and/or analyzed during the current study are available from the corresponding author on reasonable request.

\section{Declarations}

Ethics approval and consent to participate

Not applicable

\section{Consent for publication}

Not applicable

\section{Competing interests}

The authors declare that there are no conflicts of interest in the publication of this manuscript.

\section{Author details}

'Department of Biodiversity, Institute of Science and High Technology and Environmental Sciences, Graduate University of Advanced Technology, Kerman, Iran. ${ }^{2}$ Department of Biotechnology, Institute of Science and High Technology and Environmental Sciences, Graduate University of Advanced Technology, Kerman, Iran. ${ }^{3}$ Department of Plant Protection, College of Agriculture, Urmia University, Urmia, Iran.

Received: 1 March 2021 Accepted: 10 May 2021

Published online: 23 May 2021

\section{References}

Alper M, Gunes H, Col B, Tunca H (2016) Bioactivities of cry gene positive Bacillus thuringiensis (Berliner) (Bacillales: Bacillaceae) strains on Ephestia kuehniella Zeller, 1879 and Plodia interpunctella (Hübner, 1813) (Lepidoptera: Pyralidae). Turkish J Entomol 40(4):365-375

Aronson Al, Shai Y (2001) Why Bacillus thuringiensis insecticidal toxins are so effective: unique features of their mode of action. FEMS Microbiol Lett 195(1):1-8. https://doi.org/10.1111/j.1574-6968.2001.tb10489.x

Banik A, Chattopadhyay A, Ganguly S, Mukhopadhyay SK (2019) Characterization of a tea pest specific Bacillus thuringiensis and identification of its toxin by MALDI-TOF mass spectrometry. Industrial Crops \& Products 137:549-556. https://doi.org/10.1016/j.indcrop.2019.05.051

Baum JA, Malvar T (1995) Regulation of insecticidal crystal protein production in Bacillus thuringiensis. Mol Microbiol 18(1):1-12. https://doi.org/10.1111/j.13 65-2958.1995.mmi_18010001.x

BenFarhat-Touzri D, Driss F, Tounsi S (2016) A promising HD133-like strain of Bacillus thuringiensis with dual efficiency to the two Lepidopteran pests: Spodoptera littoralis (Noctuidae) and Ephestia kuehniella (Pyralidae). Toxicon 118:112-120. https://doi.org/10.1016/j.toxicon.2016.04.045

Boukedi H, Sellami S, Ktari S, Hassan NBB, Sellami-Boudawara T, Tounsi S, Abdelkefi-Mesrati L (2016) Isolation and characterization of a new Bacillus thuringiensis strain with a promising toxicity against lepidopteran pests. Microbiol Res 186-187:9-15. https://doi.org/10.1016/j.micres.2016.02.004

Bravo A, Pacheco S, Gómez I, Garcia-Gómez B, Onofre J, Soberón M (2017) Insecticidal proteins from Bacillus thuringiensis and their mechanism of action. In: Fiuza LM, Polanczyk RA, Crickmore N (eds) Bacillus thuringiensis and Lysinibacillus sphaericus characterization and use in the field of biocontrol. Springer International Publishing AG, Switzerland, p 288. https://doi.org/10.1 007/978-3-319-56678-8_4

Bravo A, Sarabia S, Lopez L, Ontiveros H, Abarca C, Ortiz A, Ortiz M, Lina L, Villalobos FJ, Peña G, Nuñez-Valdez M-E, Soberón M, Quintero R (1998) Characterization of cry genes in a Mexican Bacillus thuringiensis strain collection. Appl Environ Microbiol 64(12):4965-4972. https://doi.org/10.112 8/AEM.64.12.4965-4972.1998

El-kersh TA, Ahmed AM, Al-sheikh YA, Tripet F, Ibrahim MS, Metwalli AAM (2016) Isolation and characterization of native Bacillus thuringiensis strains from Saudi Arabia with enhanced larvicidal toxicity against the mosquito vector Anopheles gambiae (s.l.). Parasite Vector 9:1-14

Ferrandis MD, Juarez-Pérez VM, Frutos R, Bel Y, Ferré J (1999) Distribution of cryl, cryll and cryV genes within Bacillus thuringiensis isolates from Spain. Syst Appl Microbiol 22(2):179-185. https://doi.org/10.1016/S0723-2020(99)80064-2

Herandeza CS, Andrewa R, Bela Y, Ferréa J (2005) Isolation and toxicity of Bacillus thuringiensis from potato-growing areas in Bolivia. J Invertebr Pathol 88(1):816. https://doi.org/10.1016/j.jp.2004.10.006

Höfte H, Whiteley HR (1989) Insecticidal crystal proteins of Bacillus thuringiensis. Microbiol Rev 53(2):242-255. https://doi.org/10.1128/MR.53.2.242-255.1989

Jalapathi SK, Jayaraj J, Shanthi M, Theradimani M, Venkatasamy B, Irulandi S, Prabhu S (2020) Potential of Cry1Ac from Bacillus thuringiensis against the tomato pinworm, Tuta absoluta (Meyrick) (Gelechiidae: Lepidoptera). Egyptian J Biol Pest Control 30(81):1-4

Juarez-perez VM, Ferrandis MD, Frutos R (1997) PCR-based approach for detection of novel Bacillus thuringiensis cry genes. Appl Environ Microbiol 63(8):2997-3002. https://doi.org/10.1128/AEM.63.8.2997-3002.1997

Kalman S, Kiehne KL, Cooper N, Reynoso MS, Yamamoto T (1995) Enhanced production of insecticidal proteins in Bacillus thuringiensis strains carrying an 
additional crystal protein gene in their chromosomes. Appl Environ Microbiol 61 (8):3063-3068. https://doi.org/10.1128/AEM.61.8.3063-3068.1995

Katoh K, Standley DM (2013) MAFFT multiple sequence alignment software version 7: improvements in performance and usability. Mole Biol Evol 30(4): 772-780. https://doi.org/10.1093/molbev/mst010

Khorramnejad A, Talaei-Hassanloui R, Hosseininaveh V, Bel Y, Escriche B (2018) Characterization of new Bacillus thuringiensis strains from Iran, based on cytocidal and insecticidal activity, proteomic analysis and gene content. BioControl. https://doi.org/https://doi.org/10.1007/s10526-018-9901-9.

Laemmli UK (1970) Cleavage of structural proteins during the assembly of the head bacteriophage T4. J Nat 227(5259):680-685. https://doi.org/10.1 038/227680a0

Maddison W, Maddison D (2015) Mesquite: a modular system for evolutionary analysis. Version 3.10. Avaliable from: http://mesquiteproject.com

Nazarian A, Jahangiri R, Salehi Jouzani G, Seifinejad A, Soheilivand S, Bagheri O, Keshavarzi M, Alamisaeid K (2009) Coleopteran-specific and putative novel cry genes in Iranian native Bacillus thuringiensis collection. J Invertebr Pathol 102(2):101-109. https://doi.org/10.1016/j.jip.2009.07.009

Nguyen LT, Schmidt HA, Von Haeseler A, Minh BQ (2015) IQ-TREE, a fast and effective stochastic algorithm for estimating maximum-likelihood phylogenies. Mole Biol Evol 32(1):268-274. https://doi.org/10.1093/molbev/ msu300

Palma L, Muñoz D, Berry C, Murillo J, Caballero P (2014) Bacillus thuringiensis toxins: an overview of their biocidal activity. Toxins 6(12):3296-3325. https:// doi.org/10.3390/toxins6123296

Park HW, Devera JA, Prins BA, Bideshi DK (2011) The dual-activity insecticidal protein, Cry2Aa, does not enhance the mosquitocidal activity of Bacillus thuringiensis subsp. israelensis. J Asia-Pacific Entomol 14(4):429-431. https:// doi.org/10.1016/j.aspen.2011.05.007

Raymond B (2017) The biology, ecology and taxonomy of Bacillus thuringiensis and related bacteria. In: Fiuza LM, Polanczyk RA, Crickmore N (eds) Bacillus thuringiensis and Lysinibacillus sphaericus characterization and use in the field of biocontrol. Springer International Publishing AG, Switzerland, p 288. https://doi.org/10.1007/978-3-319-56678-8_2

Saadaoui I, Al-Thani R, Al-Saadi F, Belguith-Ben Hassan N, Abdelkefi-Mesrati L, Schultz P, Rouis S, Jaoua S (2010) Characterization of Tunisian Bacillus thuringiensis strains with abundance of kurstaki subspecies harbouring insecticidal activities against the lepidopteran insect Ephestia kuehniella. Curr Microbiol 61 (6):541-548. https://doi.org/10.1007/s00284-010-9650-1

Salama HS, Abd El-Ghany NM, Saker MM (2015) Diversity of Bacillus thuringiensis isolates from Egyptian soils as shown by molecular characterization. J Genet Eng Biotechnol 13(2):101-109. https://doi.org/10.1016/j.jgeb.2015.10.001

Salehi Jouzani G, Pourjan Abad A, Seifinejad A, Marzban R, Kariman K, Maleki B (2008) Distribution and diversity of dipteran-specific cry and cyt genes in native Bacillus thuringiensis strains obtained from different ecosystems of Iran. J Ind Microbiol Biotechnol 35(2):83-94. https://doi.org/10.1007/s1 0295-007-0269-6

Sambrook J, Frisch EF, Maniatis T (1989) Molecular cloning: a laboratory manual. Cold Spring Harbor Laboratory Press, New York

Seifinejad A, Salehi Jouzani GR, Hosseinzadeh A, Abdmishani C (2008)

Characterization of Lepidoptera-active cry and vip genes in Iranian Bacillus thuringiensis strain collection. Biol Control 44(2):216-226. https://doi.org/10.1 016/j.biocontrol.2007.09.010

Swiecicka I, Bideshi DK, Federici BA (2008) Novel isolate of Bacillus thuringiensis subsp. thuringiensis that produces a quasicuboidal crystal of Cry1 Ab21 toxic to larvae of Trichoplusia ni. Appl Environ Microbiol 74(4):923-930. https://doi. org/10.1128/AEM.01955-07

Tamez-Guerra P, Damas G, Iracheta MM, Oppert B, Gomez-Flores R, RodriguezPadilla C (2006) Differences in susceptibility and physiological fitness of Mexican field Trichoplusia ni strains exposed to Bacillus thuringiensis. J Econ Entomol 99(3):937-945. https://doi.org/10.1093/jee/99.3.937

Travers RS, Martin PAW, Reichelderfer CF (1987) Selective process for efficient isolation of soil Bacillus spp. Appl Environ Microbiol 53(6):1263-1266. https:// doi.org/10.1128/AEM.53.6.1263-1266.1987

Yılmaz S, Ayvaz A, Akbulut M, Azizoglu U, Karabörklü S (2012) A novel Bacillus thuringiensis strain and its pathogenicity against three important pest insects. J Stored Prod Res 51:33-40. https://doi.org/10.1016/j.jspr.2012.06.004

\section{Publisher's Note}

Springer Nature remains neutral with regard to jurisdictional claims in published maps and institutional affiliations.

\section{Submit your manuscript to a SpringerOpen ${ }^{\circ}$ journal and benefit from:}

- Convenient online submission

- Rigorous peer review

- Open access: articles freely available online

- High visibility within the field

- Retaining the copyright to your article

Submit your next manuscript at $\boldsymbol{\nabla}$ springeropen.com 